\title{
Mediator Role of Organizational Commitment to Performance
}

\author{
Nurluviyana ${ }^{\bowtie}$, Ketut Sudarma \\ Management Department, Faculty of Economics, Universitas Negeri Semarang, Semarang, Indonesia
}

\author{
Article Information \\ Article History: \\ Received September 2020 \\ Approved November 2020 \\ Published December 2020

\section{Keywords:} \\ Spiritual Leadership, \\ Quality of Work Life, \\ Performance, Organi- \\ zational Commitment
}

\begin{abstract}
The aims of this study is to determine the effect of spiritual leadership and quality of work life on performance with organizational commitment as a mediation on employees of Wimarion Hotel Semarang. The type and design of the research used in this study is quantitative research. Sampling in this study using a saturated sampling system and obtained the sample size that must be used is 70 employees. The analytical method used is the test instrument (validity and reliability), classic assumption test, and hypothesis testing with IBM SPSS Verse 23 and mediation testing with Sobel test. Application methods of data collection using interviews, quetionnares, and literature studies. The result of this study show that all of seven hypotheses were accepted. Therefore could be known that spiritual leadership has a positive and significant effect on organizational commitment. Quality of work life has a positive and significant effect on organizational commitment. Spiritual leadership has a positive and significant effect on performance. Quality of work life has a positive dan significant effect on performance. Organizational commitment has a positive and significant effect on performance. Organizational commitment is able to mediate the relationship between spiritual leadership and performance. And organizational commitment is able to mediate the relationship between quality of work life and performance.
\end{abstract}

\section{INTRODUCTION}

The era of globalization has hit various aspects of human life, on of which is the economic aspect. Globalization brings many opportunities as well as challenges for global and local companies, this makes companies need to adjust themselves in order to compete (Murty, 2012). In order for a company to survive competition, it needs to improve the quality of human resources (Murniasih \& Sudarma, 2016). Therefore, human resources are a challenge for company management (Ranihusna, 2010). However, many companies focus too much on technology and systems rather than people and ignore the fact that human resources drive these technologies and systems (Beloor et al., 2017).

A company consists of people who work to achieve this, several efforts in terms to be made to manage the company, especially in terms of improving the performance and organizational performance, depending on the performance of individuals within the company (Hermawati \& Mas, 2016). The competitive ability of a company depends on how individuals can specifically perform performance which describes the overall organizational performance (Rubel \& Kee, 2014).

Employee performance is a consequence of the efforts made by employees, if the quantity and quality achieved by employees increase, the company will be considered effective (Culbertson et al., 2013). In service companies, performance is determined through the attitude, behaviour and service to customers, whether that occurs in direct and indirect interactions (Milaningrum et al., 2019). Employee will perform well with owning intelligence, skills, and equipped with motivation and existence opportunity from environment. Opportunities from the environment will be negated

(C) 2020 Universitas Negeri Semarang 
obstacles blocking employees to do their job well so, employee performance will optimal (Handayani, 2013).

There are several factors that can improve employee performance with creates an atmosphere that is comfortable working environment to support the expected emotions, also believe in openness in every meeting or other work activities in order to train the understanding of the way of thinking of others in every opinion which possessed (Rahmasari \& Wulansari, 2020). Also factors such as a work environment, compensation, training and development, career, job security, leadership and interpersonal relationship (Thakur \& Sharma, 2019).

Leadership plays an important role in determining and improving employee performance because the leadership role is needs to align different needs and to create a conducive work environment and it's the leader who will move and direct employees to achieve company goals (Hidayah \& Sutopo, 2017). A leader must choose a leadership style that is suitable to be applied in his company that can motivate employees and discipline employees in the company (Pawirosumarto et al., 2017).

The most effective leadership style is a leadership style that encourages and motivates employees, fosters positive employee attitudes towards work and the company and easily adapts to various situations (Rawung, 2013). Spiritual leadership includes motivating and inspiring employees through a vision and organizational culture based on altruistic love. It is necessary to satisfy the basic needs of leaders and followers for spiritual wellbeing through calling and membership across individuals, to be empowered at the team and organizational levels and to promote higher employee welfare, commitment and productivity as well as responsibility and performance (Fry, 2003).

There are differences in the results of previous research regarding the relationship between spiritual leadership and performance. Research conducted by Fry et al. (2016) which states that higher spiritual leadership will have a positive effect on employee performance. However, research conducted by Baykal and Zehir (2018) obtained different results which stated that spiritual leadership has no positive effect on employee performance.

Quality of work life is very important for the smooth running of a company. To help attract and retain employees who are efficient and effective according to their job profiles, which lead to employee and company success (Ojedokun et al., 2015). Dissatisfaction with the quality of work life is a problem that affects all employees during their career regardless of status and position and will have a negative impact on employees and the company (Srivastava \& Pathak, 2016).

When thinking of employees as human beings, they struggle in their daily lives starting from household duties, traffic and so on which have an impact on the efforts made by employees in the workplace. Employees are looking for a company that provides a healthy quality of work life that allows them to balance work and personal commitments and feel productive and valued. By understanding what employees are looking for at the organizational level it will be possible to achieve goals and maintain the market while at the individual level it will increase welfare and provide better performance (Badawy et al., 2018).

Research differences were found on the influence of the quality of work life and performance. Such as research conducted by Hermawati and Mas (2017); Thakur and Sharma (2019) which states that the quality of work life has a positive and significant effect on employee performance. However, research conducted by Radja et al. (2013); Ramadhoan (2015) gave results that quality of work life was found to have no positive effect on performance.

Employee commitmenet to their organization can be an important instrument to improve performance and become a fundamental problem for the organization owner and management (Rahmawaty, 2016; Hafiz, 2017). Employee commitment to the organization is marked by acceptance of organizational values, willingness to do greater effort and want to maintain membership in the organization, employee commitment will increase if given the opportunity to do important and challenging work, meet and interact with new people and learn skills and can develop personally (Azeem \& Akhtar 2014). Employee with a high level of commitment will be willing to give more responsibility to drive the success of their organization (Wartini \& Harjiyanti, 2014).

In accordance with previous research, it is known that the variable organizational commitment can act as a mediating variable for the influence of spiritual leadership and quality of work life on employee performance. Research conducted by Nayak and Sahoo (2015) found that commitment partially mediates the relationship between spiritual leadership and employee performance. And also research conducted by Ramadhoan (2015) found that th commitment mediates the relationship between the quality of work life and employee performance.

Based on the interview of HRD Staff obtained that hotel always pays attention to the needs of employees at work. Job descriptions are made according to work and working hours and emp- 
loyee placement according to the skills they have. 24 working hours for operational employees are made in shifts or alternately and shift changes are made fairly. In terms of compensation, the hotel always provides compensation twice a month namely providing salaries and providing service charges. However, so far there are still employees who have not been maximal in carrying out their duties. They demanded their rights to be fulfilled, but they were not balanced with maximum performance.

The results of interviews with several employees revealed that the department heads had given attention and concern to employees, such as reprimanding employees who made mistakes in their work then defending and providing solutions to the impact of the mistakes made by employees. In addition, leaders also emphasize the aspects of honesty related to their work and encourage them to work wholeheartedly. However, the application of spirituality in leading employees is considered insufficient, this is evidenced by the fact that there are still employees who work not wholeheartedly so that the resulting performance is not optimal.

Based on the description of the background of the above problems, the authors are interested in doing research with the title, "Mediator Role Analysis of Organizational Commitment to Improve Performance".

\section{Hypotheses Development Spiritual Leadership on Organizational Com- mitment}

A leader must be able to choose what leadership style is suitable for the organization in order to motivate and discipline employees $(\mathrm{Pa}-$ wirosumarto et al., 2017). Spiritual leadership is a leadership style that not only emphasizes aspects of character and behavior but also emphasizes spiritual values into the workplace. A spiritual leader understands the importance of employees finding meaning in their work and shows genuine concern for employees (Mansor et al., 2013). According to Fry (2003), having a sense of being understood and valued is largely a matter of reciprocity and connection through social interaction and membership. This means that when the organization understands its members and respects them, employees become loyal to the organization.

The purpose of spiritual leadership is to create a vision and value conformity across individuals to be empowered at the team and organizational levels and ultimately to encourage higher levels of organizational commitment and productivity (Fry, 2003). Research conducted by Mansor et al., (2013); Dargahi et al. (2017); Akbar et al. (2018); Rumangkit (2020) show that spiritual leadership has a positive and significant effect on organizational commitment. Therefore, the proposed hypothesis is:

H1: Spiritual Leadership can improve the organizational commitment

\section{Quality of Work Life on Organizational Com- mitment}

The internal and external environment of the organization has changed rapidly due to economic conditions social changes and changes in the unstable work environment. These changes directly affect employees in the organization, employees are asked to adapt according to new existing policies. This can have both positive and negative effects. The positive effect is that the organization will have more efficient management and employees who are dedicated and enthusiastic with a common goal, but the negative effect is that employees do not have organizational commitment, behave badly and decrease job satisfaction (Traiyotee et al., 2019). Organizations are required to realize and prioritize satisfaction, working conditions, facilities and work environment for employees that can result in a better quality of work life.

Quality of work life approach aims to increase organizational efficiency by protecting the physical and mental health of employees (Chinomona \& Dhurup, 2014). By fulfilling the quality of work life, it can bring employees comfort at work so that it will increase employee dedication and loyalty to the organization. Research conducted by Chinomona and Dhurup (2014); Ojedokun et al. (2015); Srivastava and Pathak (2016); Akar (2018); Traiyotee et al. (2019) found that the quality of work life has a positive and significant impact on organizational commitment. Therefore, the proposed hypothesis is:

H2: Quality of Work Life can improve the organizational commitment

\section{Spiritual Leadership on Performance}

Fry (2003) argues that the concept of spiritual leadership is very important in facing the challenges of an organizational environment in the $21^{\text {st }}$ century which is full of rapid changes. Rapid changes in social, political and economic fields create a feeling of uncertainty in the work environment and job opportunities, this makes companies required to retain employees by recognizing their spiritual values (Twigg \& Parayitam, 2007). The purpose of spiritual leadership is to meet the basic needs of leaders and followers, namely spiritual well-being through calling and membership, to create a vision and value conformity at the individual level, to empower teams and organizations and to encourage higher organizational commitment and 
productivity (Fry \& Cohen, 2009). Employee performance is a consequence of the efforts made by employees, if the quantity and quality achieved by employeed increase, the organization will be considered an effective organization (Culbertson et al., 2013).

Through the implementation of the vision by the company which include how well the employees know the company's vision, how much influence it has there is a company vision for employees and the effect on performance according to employees. Spiritual leadership can too seen through the hope which includes how much faith and sacrifice what employees will do to the company, how much employees maintain and hard wor to help success company, how well the employees carry out their work, and how high are the employees expectations for internal success company (Wulandari \& Sudarma, 2017). Research conducted by Musta'in et al. (2014); Salehzadeh et al. (2015); Wibowo et al. (2015) found that spiritual leadership has a positive effect on employee performance, the more trusted a leader is, the better the employee is at doing his job. Therefore, the proposed hypothesis is:

H3: Spiritual Leadership can improve the performance

\section{Quality of Work Life on Performance}

Quality of work life is very important for organizations to continue to attract and retain efficient and talented employees who are able to carry out their duties effectively and whole-heartedly (Ojedokun et al., 2015). Department-wide programs aimed at increasing employee satisfaction, strengthening workplace learning and helping employees better manage change and transition. Dissatisfaction with the quality of work life is a problem that affects all employees regardless of position or status (Saraji \& Dargahi, 2006). This problem will have an impact on all activities carried out by employees in an organization. Work results are one of the ultimate goals of employee activities in the workplace and are the builders of organizational goals.

The quality of work life is very important related to the smooth functioning of an organization. Research conducted by Mohammadi et al. (2016) found that three of the eight indicators of the quality of work life, namely adequate and fair compensation, social relations and work safety have no effect on performance. Meanwhile, research of Thakur and Sharma (2019) shows that the quality of employee work life has a positive impact on two dimensions of performance namely task performance, contextual performance and a negative impact on counterproductive work behavior.
Other results indicate that the quality of work life has a direct effect on employee performance, the higher the quality of work life received by employees, the higher the employees performance (Hermawati \& Mas, 2017; Widayanti \& Palupiningdyah, 2019). Therefore, the proposed hypothesis is:

H4: Quality of work life can improve performance

\section{Organizational Commitment on Performance}

Organizational commitment is on of the most basic concepts in relation to employee motivation and productivity. Employee with strong commitment will work harder to contribute to organizational performance. Organizations need high-performing members to meet goals, provide the best service and achieve a competitive advantage. Employee who identify and are involved in their organization, will retain their membership in the organization and put all efforts on its behalf (Rageb et al., 2013). Commitment is a behavior that is consistent with activities, so that the higher the employee's commitment to the organization can improve the employee's performance (Murty, 2012).

Research conducted by Raza et al. (2014) show that organizational commitment has a positive effect on employee performance. This is in line with Hafiz (2017) research which found tht organizational commitment has a positive effect on performance. This means that employees are willing to devote all efforts and remain in the organization to complete the goals of the work because they have the same goals and values in the organization. Therefore, the proposed hypothesis is: H5: Organizational commitment can improve performance

\section{Organizational Commitment Mediates the Ef- fect of Spiritual Leadership on Performance}

Employee who have high performance are neede by organizations to achieve goals effectively and efficiently. One of the factors that influence employee performance is commitment. Meanwhile, the level of performance and organizational commitment of employees cannot be separated from the influence of the leader. Spiritual leadership style is considered as a leadership style that is suitable in complex situations. Spiritual leadership style that is based on morality and supports goodness, righteousness and teamwork. According to Fry (2003) the previous leadership style was not able to participate environmental changes and did not support the meaning of life. Many people work only to make ends meet and status, not because they love their jobs and find meaning in life through their work. Spiritual leadership style are initiated to help employees find work meaning. 
Spiritual leadership provides an integrated framework to increase intrinsic motivation, commitment and productivity (Fry et al., 2005). Research conducted by Akbar et al. (2018) found that organizational commitment mediates the relationship between spiritual leadership and employee performance. When employees feel safe, satisfied and connected with the organization, they will be committed to their work. Therefore, the proposed hypothesis is:

H6: Organizational commitment mediates the effect of spiritual leadership in improving performance

\section{Organizational Commitment Mediates the Ef- fect of Quality of Wok Life on Performance}

Quality of work life is on of the most important factors in measuring employee organizational behavior. One way to improve the quality of work life for employees is to improve the quality of their work environment. Apart from the work environment, other factors that affect the quality of work life are the relationship with managers, working conditions, work perceptions, service support and rewards (Zhao et al., 2013). By increasing the quality of their work environment it will increase employee loyalty and performance. Employees who wish not to attend or leave their jobs will affect job satisfaction, success, commitment and quality of work life (Applebaum, 2010). Employee dissatisfaction with work life arise because of the mismatch between employee expectations and reality that can affect employee performance in the organization.

Employee expect more of the financial benefits from the organization because they have to spend most of their time in the organization. Employees expect to have quality time at work which will increase their sense of belonging and attachment to the organization. In organizations, the wuality of work life is very important for the smooth running of the organization. To help attract and retain employees who efficiently and effectively fit their job profiles, leading to employee and organizational success. Ensuring the quality of work life is very important for the organization to make employees more committed to organizational development (Rubel \& Kee, 2014).

Research conducted by Nayak and Sahoo (2015); Ramadhoan (2015) found an indirect influence between the quality of work life on employee performance, namely through organizational commitment as mediator. If you want to improve performance through the quality of work life you must first create and increase organizational commitment, because commitment contains conditional aspects that aplly in general to all members of the organization and the organization itself. Therefore, the proposed hypothesis is:

$\mathrm{H} 7$ : Organizational commitment mediates the effect of quality of work life in improving performance

Based on the development of hypotheses the following research models can be formed:

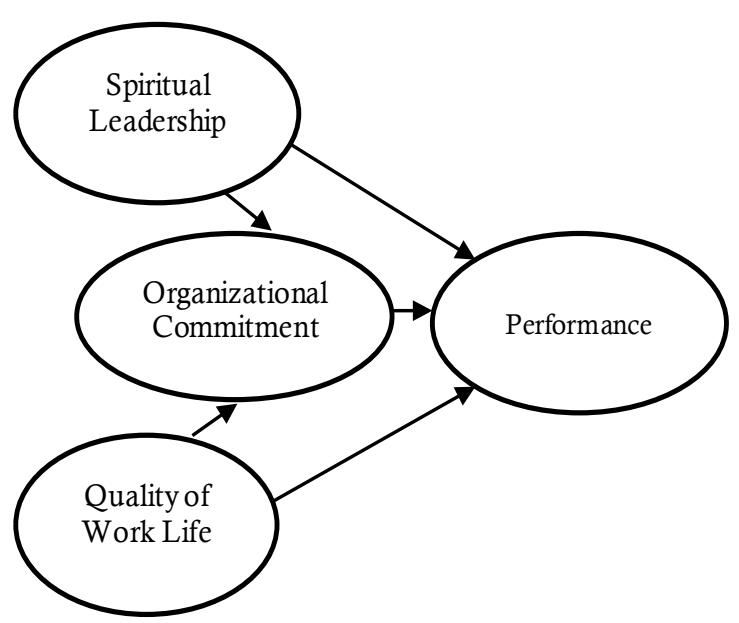

Figure 1. Research Model

\section{METHOD}

The population used in this study were employees at Wimarion Hotel Semarang with a total 70 people. The sampling technique used saturated samples so that all populations in this study were used as research samples. Data collection techniques through questionnaires using a Likert scale 1-5 and interviews with HRD staff and head of Front Office department. The data analysis technique used descriptive analysis method, hypothesis testing, path analysis using SPSS program version 23 and Sobel test.

The variables in this study are spiritual leadership with indicators of vision, altruistic love and hope. Variable quality of work life with indicators of work environment, organizational culture, relations and cooperation training and development, compensation and rewards, facilities and work safety, job satisfaction and security, job outonomy, and adequacy of resources. Variable organizational commitment with indicators of affective commitment, norma-tive commitment and continuence commitment. Meanwhile, the performance with indicators of quality, work efficiency, initiative, self-development, cooperation, and focus on positive things. 


\section{RESULTS AND DISCUSSION}

\section{Instrument Validity}

Validity test is used to measure wthether a questionnaire is valid or not (Ghozali, 2016). A questionnaire is said to be valid if the questions in the questionnaire are able to reveal something that the questionnaire measures (Ghozali, 2016). Validity is a measure that shows the levels of validity and validity of an instrument (Suharsimi, 2010). In this study, to test the validity of the data using IBM SPSS version 23 computer program.

According to Ghozali (2016), the significance test is carried out by comparing the calculated $\mathrm{r}$ value with the $\mathrm{r}$ table for degree of freedom $(d f)=n-2$, in this case $n$ is the number of samples. If in the output display the Pearson Correlation $r$ count $\geq r$ table and the value is positive, then the statement item is valid. The number of respondents in this validity test was 30 employees of Wimarion Hotel Semarang. With 30 respondents, the value $(\mathrm{df})=30-2=28$, it can be seen that the value of $\mathrm{r}$ table with a significant level $5 \%$ is 0.361 . A statement item is said to be valid if $r$ count $>r$ table (0.361), and it is said to be invalid if $\mathrm{r}$ count $<\mathrm{r}$ table $(0.361)$.

In this study using 58 question items, where the performance variable consists of 13 questions spiritual leadership 10 questions, quality of work life 24 questions and organizational commitment 11 questions.

The results of the validity test on the performance variable show that 13 questions have $r$ count $>r$ table. The question items for performance variables are taken from the article of Koopmans et al. (2011) with an example of the question "I remember the results that must be achieved in work". Thus it can be said that 13 items of performance questions are declared valid and can be used in further data collection.

The results of the validity test on the spiritual leadership variable showed that the 10 questions items had a value of $r$ count $>r$ table. The spiritual leadership question items is taken from the article of Fry (2003) with an example of question "I understand and committed to the vision of the hotel". Thus it can be said that the 10 items of spiritual leadership variable questions are valid and can be used in further data collection.

The results of the validity test of the quality of work life variable indicate that 24 question items have a value of $r$ count $>r$ table. The question items on the quality of work life variables were taken from the article of Swamy et al. (2015) with an example of the question "The working environment and working conditions in my hotel are good and motivationg". Thus it can be said that 24 items quality of work life variable questions are declared valid and can be used in further data collection.

The results of the validity test of the organizational commitment variable showed that 1 question out of 12 questions was invalid with a calculated $r$ value of $0.175<r$ table 0.361 . organizational commitment variable question items are taken from the article of Allen and Meyer (1990) with an example of the question "I feel the problem in the hotel is like my own problem". So that invalid questions are eliminated and 11 other questions that are declared valid are used for further data retrieval.

\section{Instrument Reliability}

A questionnaire is said to be reliable if a person's answer to a statement is consistent or stable over time (Ghozali, 2016). Reliability test was carried out using the Cronbach Alpha coefficient. SPSS provides facilities to measure reliability with the Cronbach Alpha $(\alpha)$. A variable is said to be reliable if it gives a Cronbach Alpha $>0.70$.

Table 1. Reliability Test Results

\begin{tabular}{lr}
\hline \multicolumn{1}{c}{ Variable } & \multicolumn{1}{c}{$\begin{array}{c}\text { Cronbach's } \\
\text { Alpha }\end{array}$} \\
\hline Performance & 0.868 \\
\hline Spiritual Leadership & 0.879 \\
\hline Quality of Work Life & 0.919 \\
\hline Organizational Commitment & 0.817 \\
\hline
\end{tabular}

From Table 1. It is known that all variables have a Cronbach Alpha $>0.70$, so that all variables are declared reliable.

\section{Descriptive Analysis}

This analysis was conducted to find out a descriptive description of the respondent's responses to each research variable (Sugiyono, 2017). Research on the index of respondents answers was carried out with the criteria of Three-Box Method (Ferdinand, 2014). Based on the research that has been done, the following results are obtained:

Table 2. Descriptive Analysis Resluts

\begin{tabular}{clrl}
\hline No & \multicolumn{1}{c}{ Variable } & Index & Category \\
\hline 1 & Performance & 72.80 & Moderate \\
\hline 2 & Spiritual Leadership & 67.25 & Moderate \\
\hline 3 & Quality of Work Life & 73.39 & High \\
\hline 4 & $\begin{array}{l}\text { Organizational Commit- } \\
\text { ment }\end{array}$ & 69.02 & Moderate \\
\hline
\end{tabular}


Based on the results of the descriptive analysis in Table 2. There are three research variables that fall into the moderate category. This shows that the spiritual leadership that is played is not optimal. In addition, the management also needs to pay attention and increase commitment so that the employee performance at Wimarion Hotel Semarang can increase.

\section{Hypothesis Testing \\ Statistical Test $\mathbf{t}$}

The $t$ statistical test aims to show how far the influence of one independent variable is on the dependent variable (Ghozali, 2016). The test was carried out with a significance level of $5 \%$ $(a=0.05)$. In this study, regression analysis was used to determine the correlation of the independent variables, namely spiritual leadership, quality of work life and organizational commitment to the dependent variable, performance.

The determination of the acceptance of the mediation effect is seen by comparing the $t$ value with $t$ table value which is known through the Sobel test. If the $t$ value is greater than $t$ table ( $t$ count $>1.96$ ) it can be concluded that there is a mediation effect (Ghozali, 2016).

\section{Hypothesis Test 1}

The $t$ test value for the spiritual leadership variabels is 3.771 with a significance value of $0.000<0.05$. So it can be concluded that H1 which states that "Spiritual leadership can improve the organizational commitment" is accepted. The direction of a positive relationship means that when spiritual leadership is high it will increase organizational commitment and when spiritual leadership is low it will decrease organizational commitment. These results are in accordance with the research conducted (Salehzadeh et al., 2015). These results are shown in Table 3.

Table 3. Hypothesis Results of Spiritual Leadership and Quality of Work Life on Organizational Commitment

\begin{tabular}{|c|c|c|c|c|c|}
\hline \multicolumn{6}{|c|}{ Coefficients $^{a}$} \\
\hline \multirow[t]{2}{*}{ Model } & \multicolumn{2}{|c|}{$\begin{array}{c}\text { Unstandard- } \\
\text { ized Coeffi- } \\
\text { cients }\end{array}$} & \multirow{2}{*}{$\begin{array}{c}\begin{array}{c}\text { Standard- } \\
\text { ized Coef- } \\
\text { ficients }\end{array} \\
\text { Beta }\end{array}$} & \multirow[t]{2}{*}{$\mathbf{t}$} & \multirow[t]{2}{*}{ Sig. } \\
\hline & B & $\begin{array}{l}\text { Std. } \\
\text { Error }\end{array}$ & & & \\
\hline $\begin{array}{l}\text { (Con- } \\
\text { stant) }\end{array}$ & 0.853 & 2.423 & & 0.352 & 0.026 \\
\hline SL & 0.376 & 0.100 & 0.362 & 3.771 & 0.000 \\
\hline QWL & 0.298 & 0.050 & 0.577 & 6.004 & 0.000 \\
\hline
\end{tabular}

\section{Hypothesis Test 2}

The $t$ test results obtained for the quality of work life variable are 6.004 with a significance value of $0.000<0.05$. So it can be conducted that $\mathrm{H} 2$ which states that "Quality of work life can improve the organizational commitment" is accepted. The direction of a positive relationship means that when the quality of work life is high it will increase organizational commitment and when the quality of work life is low it will decrease organizational commitment These results are in accordance with the research conducted (Thakur \& Sharma, 2019). These results are shown in Table 3.

Table 4. Hypothesis Test Results on Spiritual Leadership, Quality of Work Life and Organizational Commitment to Performance Coefficients $^{\mathrm{a}}$

\begin{tabular}{lccccc}
\hline Model & \multicolumn{2}{c}{$\begin{array}{c}\text { Unstandard- } \\
\text { ized Coeffi- } \\
\text { cients }\end{array}$} & $\begin{array}{c}\text { Stan- } \\
\text { dardized } \\
\text { Coeffi- } \\
\text { cients }\end{array}$ & $\mathrm{t}$ & Sig. \\
& $\mathrm{B}$ & $\begin{array}{c}\text { Std. } \\
\text { Error }\end{array}$ & Beta & & \\
\hline $\begin{array}{l}\text { (Con- } \\
\text { stant) }\end{array}$ & 11.777 & 2.295 & & 5.131 & 0.000 \\
\hline SL & 0.249 & 0.104 & 0.168 & 2.397 & 0.019 \\
\hline QWL & 0.362 & 0.058 & 0.491 & 6.215 & 0.000 \\
\hline OC & 0.489 & 0.116 & 0.343 & 4.229 & 0.000 \\
\hline
\end{tabular}

\section{Hypothesis Test 3}

The result show that $t$ test value for the spiritual leadership variable is 2.397 with a significance level of $0.019<0.05$. So it can be concluded that $\mathrm{H} 3$ which states that "Spiritual leadership can improve the performance" is accepted. The direction of a positive relationship means that when spiritual leadership is high it will increase performance and when spiritual leadership is low it will decrease performance. These results are in accordance with the research conducted (Salehzadeh et al., 2015). These results are shown in Table 4.

\section{Hypothesis Test 4}

The results that $t$ test results obtained for the quality of work life variable were 6.217 with a significance value of $0.000<0.05$. So it can be concluded that $\mathrm{H} 4$ which states that "Quality of work life can improve the performance" is accepted. The direction of a positive relationship means that when the quality of work life is high 
it will increase performance and when the quality of work life is low it will decrease performance. These results are in sccordance with the research conducted (Thakur \& Sharma, 2019). These results are shown in Table 4.

\section{Hypothesis Test 5}

The results that $t$ value test for the organizational commitment variable are 4.229 with a significance value of $0.000<0.05$. So it can be concluded that H5 which states that "Organizational commitment can improve the performance" is accepted. The direction of a positive relationship means that when organizational commitment is high it will increase performance and when organizational commitment is low it will decrease performance. These results are in accordance with the research conducted (Fitriastuti, 2013; Hafiz, 2017). These results are shown in Table 4.

\section{Path Analysis Test}

Path analysis is used to estimate the causality relationship between variables using regression analysis based on predetermined theory (Ghozali, 2016). This study will examine the influence of spiritual leadership and the quality of work life on performance through organizational commitment. To measure the presence or absence of the effect of mediation, here are the results of the calculation of the direct relationship, indirect relationship and total indirect relationship between the variables of spiritual leadership, quality of work life, organizational commitment, and first comparison of path coefficients. The path coefficient is coefficient is calculated by creating two regression model equations.

First Examination:

$\mathrm{OC}=\mathrm{b}_{1} \mathrm{SL}+\mathrm{b}_{2} \mathrm{QWL}+\mathrm{e}_{1}$

$\mathrm{OC}=\left(0.362 \mathrm{SL}+(0.577 \mathrm{QWL})+\mathrm{e}_{1}\right.$

Second Examination:

$\mathrm{P}=\mathrm{b}_{1} \mathrm{SL}+\mathrm{b}_{2} \mathrm{QWL}+\mathrm{b}_{3} \mathrm{OC}+\mathrm{e}_{2}$

$\mathrm{P}=(0.168 \mathrm{SL})+(0.491 \mathrm{QWL})+(0.343 \mathrm{OC})+\mathrm{e}_{2}$

Explanation:

$$
\begin{array}{ll}
\text { SL } & =\text { Spiritual Leadership } \\
\text { QWL } & =\text { Quality of Work Life } \\
\text { OC } & =\text { Organizational Commitment } \\
\text { P } & =\text { Performance }
\end{array}
$$

Based on the results of the relationship path analysisforeachvariableshownin theimagebelow:

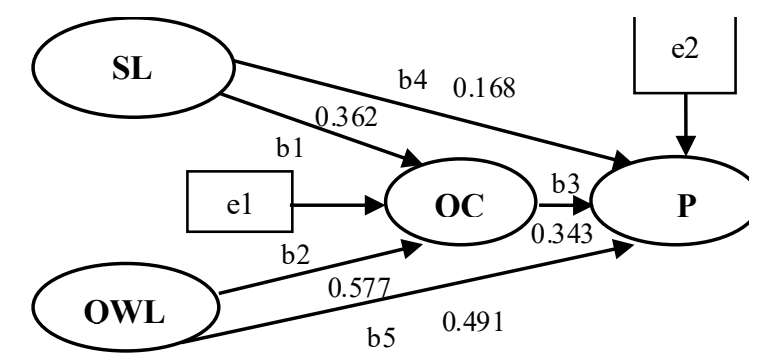

Figure 2. Path Analysis Result

\section{Sobel Test}

Sobel test is done by testing the strength of the direct and indirect influence of the independent variable on the dependent variable through the mediating variable. Determination of acceptance of the effect of mediation is seen by comparing the $t$ value with the $t$ table value. If the $t$ value is greater thatn $t$ table ( $t$ count $>1.96$ ) it can be concluded that there is a mediation effect (Ghozali, 2016). Based on Figure 2 it can be seen that:

Direct effect $\left(b_{5}\right)=0,491$

Indirect effect $\left(b_{2} \times b_{3}\right)$

$=0.577 \times 0.343=0.197911$

Total effect of path ceofficients $\left(b_{4}+\left(b_{2} \times b_{3}\right)\right)$

$=(0.491+0.197911)=0.688911$

Count with Sobel Test

$$
\begin{aligned}
& \mathrm{Sab}=\sqrt{\mathrm{b}^{2} \mathrm{Sa}^{2}+\mathrm{a}^{2} \mathrm{Sb}^{2}+\mathrm{Sa}^{2} \mathrm{Sb}^{2}} \\
& \mathrm{Sab}=\sqrt{0,003074}=0,554
\end{aligned}
$$

Calculating the $t$ value of the mediation effect statistic:

$$
\mathrm{t}=\frac{\mathrm{ab}}{\mathrm{Sab}}=\frac{0.124166}{0.0554}=2.239361
$$

Based on the results of the calculation of the Sobel test, the $t$ count is 2.239361 . This value is greater than the $\mathrm{t}$ table, namely ( $\mathrm{t}$ count $=$ $2.239361>t$ tabel $=1.9686$ ). So it can be concluded that H6 which states "Organizational commitment mediates the effect of spiritual leadership in improving performance" is accepted. This shows that if the spiritual leadership applied by the leaders of the Wimarion Hotel Semarang is high and is balanced with organizational commitment by employee it will improve employee performance. The results of this study are in accordance with the research conducted by (Akbar et al., 2018).

Spiritual leadership that has not been maximized must be improved by increasing under- 
standing of the company's vision and interpreting work not only as a tool to earn money. In addition leaders must encourage employees to be able to face problems in any situation or be able to adapt to the various roblems they encounter while carrying out work. With this adaptability can improve performance. However, in practice, there are still employees who have difficulty adjusting to changing work situations.

Efforts that have been made by Wimarion Hotel Semarang include increasing non-financial compensation such as conducting joint activities with all employees and provding equal opportunities for all employees to get promotion. By increasing non-financial compensation, it is hoped that it can increase the sense of pride, sense of belonging and enthusiasm of employees as part of the company and then foster commitment from within the employees themselves. However, the joint activities carried out by the hotel for all of its employees have not run optimally because it is only carried out once a year and because the activities are carried out outside the city so that some employees think again about their participation. Based on Figure 2, it can be seen that:

Direct effect $\left(b_{5}\right)=0.491$

Indirect effect $\left(b_{2} \times b_{3}\right)$

$=0.577 \times 0.343=0.197911$

Total effect of path coefficients $\left(b_{4}+\left(b_{2} x_{3}\right)\right)$

$=(0.491+0.197911)=0.688911$

Counting with Sobel Test

$$
\begin{aligned}
& \mathrm{Sab}=\sqrt{\mathrm{b}^{2} \mathrm{Sa}^{2}+\mathrm{a}^{2} \mathrm{Sb}^{2}+\mathrm{Sa}^{2} \mathrm{Sb}^{2}} \\
& \mathrm{Sab}=\sqrt{0,004808}=0,0693
\end{aligned}
$$

Calculating the t-value of the mediation effect:

$$
\mathrm{t}=\frac{\mathrm{ab}}{\mathrm{Sab}}=\frac{0,197911}{0,0693}=2.854324
$$

Based on the results of the calculation of the Sobel test, the $t$ count is 2.85 . This value is greater than $\mathrm{t}$ table which is 1.9686 ( $\mathrm{t}$ count $=$ $2.85>\mathrm{t}$ table $=1.9686$ ). So it can be concluded that $\mathrm{H} 7$ which states "Organizational commitment to mediate the influence of the quality of work life in improving performance" is accepted. The results of this study are in accordance with research conducted by (Ramadhoan, 2015).

The quality of work life that employees get from the company shows that the company is trying to increase the commitment felt by employees. Employees who get a god quality of work life will be more enthusiastic in completing all their work and will also be motivated to work and provide the best for the company. The performance index value several indicators that are sill classified as moderate is the result of the lack of optimal fulfillment of employees needs to support their performance. Leaders and manangers must use a variety of strategies that can increase employee commitment to the organization such as developing trust and fairness towards employees, developing trust and support which can help employees improve their performance.

The efforts have been made by Wimarion Hotel Semarang in providing facilities for employees such as lockers, prayer rooms and also improving work safety arrangements making evacuation route signs clearer. In addition, the company also gives employees the freedom to decide what finishing methods they want to use to complete their work. As well as to increase the adequacy of resources, the company implemented a cleare and easier flow for communication and information exchange by using various ways of communication methods such as telephone, WhatsApp, email, and Power Pro Software. When communication runs well, all information can be absorbed properly so there is no misunderstanding of the information interpretation. With smooth communication between individuals and between departments it will make it easier to complete work so that the work obtained is as expected. However, there are still frequent misinterpretations and delays in receiving information which results in disruption of work processes. This happens because the existing internet network is sometimes unstable and has not spread throughout the employees rooms.

\section{CONCLUSION AND RECOMMENDATION}

The test results prove that spiritual leadership and quality of work life can improve organizational commitment. The findings in this study prove that spiritual leadership and quality of work life can improve the performance. The findings in this study prove that organizational commitment can improve performance. The findings in this study prove that organizational commitment can mediate the relationship between spiritual leadership and performance. The findings in this study prove that organizational commitment can mediate the relationship between quality of work life and performance.

Suggestions for future research are expected to be able to carry out research on the same aspects to test the consistency of the results of this study by expanding the research sample in 
various fields so that the research results can be generalized. In addition, it can develop other variables that can mediate the influence of spiritual leadership and quality of work life on performance such as work attachment or motivation.

Suggestions for Management Wimarion Hotel Semarang to improve spiritual leadership is that leaders must cultivate genuine concern, empathy, trust and respect, encourage employees to continue to develop their potential, discuss and handle employee weaknesses or shortcomings wisely. To improve quality of work life are by providing more frequent training and providing equal opportunities for all employees to get training. As well as to smooth the flow of communication, management can add alternative communication using walkie talkies because some departments have work office in the basement where the signal in the room is not good and extends the internet network. To improve organizational commitment are by adding gathering/outing activities that can be done inside the hotel environment and holding hotel anniversary celebrations, new year celebrations with all employees. And also give greetings and make posters to employee birthday.

\section{REFERENCES}

Akar, H. (2018). A Meta-Analytic Study Concerning the Effect of Educational Stakeholders' Perceptions of Quality of Work Life on Their Job Satisfaction and Organizational Commitment. International Online Journal of Educational Sciences, 10(3), 101-115.

Akbar, A. B., Wahyudi, S., \& Djastuti, I. (2018). Spiritual Leadership and Employee Performance: Mediating Role of Organizational Commitment in Indonesian Public University. Jour nal of Engineering and Applied Science, 13(12), 4344-4352.

Allen, N. J., \& Meyer, J. P. (1990). The measurement and antecedents of affective, continuance and normative commitment to the organization. 1-18..

Azeem, S. M., \& Akhtar, N. (2014). The Influence of Work Life Balance and Job Satisfaction on Organizational Commitment of Healthcare Employees. International Journal of Human Resources Studies, 4(2), 18-24.

Badawy, T. A. El, Chinta, R., \& Magdy, M. M. (2018). Does "Gender" Mediate or Moderate the Relationship Between "Quality of Work Life" and "Organizational Commitment"? Evidence from SMEs in Egypt. Gender in Management: An International Journal.

Baykal, E., \& Zehir, C. (2018). Mediating Effect of Psychological Capital on the Relationship Between Spiritual Leadership and Performance. Business Administration and Management, 21(3), 124-140.
Beloor, V., Nanjundeswaraswamy, T. S., \& Swamy, D. R. (2017). Employee Commitment and Quality of Work Life - A Literature Review. The International Journal of Indian Psychology, 4(2).

Chinomona, R., \& Dhurup, M. (2014). The Influence of the Quality of Working Life on Employee Job Satisfaction, Job Commitment and Tenure Intention in the SMW Sector Zimbabwe. $S A$ JEMS NS, 17(4), 363-378.

Culbertson, S. S., Huffcutt, A. I., \& Goebl, A. P. (2013). Introduction and Empirical Assessment of Executive Functioning as a Predictor of Job Performance. PcyCh Journal, 1-11.

Dargahi, H., Abdochalli, N., \& Rahmadi, H. (2017). An Investigation of Relationship Between Spiritual Leadership Style with Organizational Commitment among Tehran University of Medical Sciences Staffs. International Journal of Asian Social Science, 7(3), 234-241.

Ferdinand, A. (2014). Metode Penelitian Manajemen. Semarang: Badan Penerbit Universitas Diponegoro.

Fitriastuti, T. (2013). Pengaruh Kecerdasarn Emosional, Komitmen Organisasional, dan Organizational Citizenship Behavior Terhadap Kinerja Karyawan. Jurnal Dinamika Manajemen, 4(2), 103-114.

Fry, L. W. (2003). Toward a Theory of Spiritual Leadership. The Leadership Quarterly, 14, 693-727.

Fry, L. W., \& Cohen, M. P. (2009). Spiritual Leadership as a Paradigm for Organizational Transformation and Recovery from Extended Work Hours Cultures. Journal of Business Ethics, 84, 265-278.

Fry, L. W., Latham, J. R., Clinebell, S. K., \& Krahnke, K. (2016). Spiritual Leadership as a Model for Performance Excellence : a Study of Baldrige Award Recipients. Journal of Management, Spirituality \& Religion, 1-26.

Fry, L. W., Vitucci, S., \& Cedillo, M. (2005). Spiritual Leadership and Army Transformation : Theory, Measurement, and Establishing a Baseline. The Leadership Quarterly, 16, 835-862.

Ghozali, I. (2016). Aplikasi Analisis Multivariate dengan Program IBM SPSS 23 (8th ed.). Semarang: Universitas Diponegoro.

Hafiz, A. (2017). Relationship between Organizational Commitment and Employee's Performance Evidence from Banking Sector of Lahore. Arabian Journal of Business and Management Review, $7(2), 1-7$.

Handayani. (2013). Etika Lembaga dan Kinerja Perawat Rumah Sakit Umum dengan Quality of Work Life sebagai Variabel Intervening. Management Analysis Journal, 2(2), 1-10.

Hermawati, A., \& Mas, N. (2016). Transglobal Leadership, Quality of Work Life, and Employee Performance in Cooperatives in East Java, Indonesia. International Journal of Business Management, 1(1), 1-8.

Hermawati, A., \& Mas, N. (2017). Mediation Effect 
of Quality of Worklife, Job Involvement, and Organizational Citizenship Behavior in Relationship Between Transglobal Leadership to Employee Performance. International Journal of Law and Management, 59(6), 1143-1158.

Hidayah, S., \& Sutopo. (2017). The Role of SpiritualBased Leadership as Predictor in Improving Employee Performance. Jurnal Dinamika Manajemen, 8(1), 83-91.

Koopmans, L., Bernaards, C. M., Hildebrandt, V. H., Schaufeli, W. B., Vet, H. C. W. De, \& Beek, A. J. Van Der. (2011). Conceptual Frameworks of Individual Work Performance - A Systematic Review. Journal of Occupational and Environmental Medicine, 53(8), 856-866.

Mansor, N., Ismail, A. H., Afifie, M., Alwi, M., \& Anwar, N. (2013). Relationship between Spiritual Leadership and Organizational Commitment in Malaysians' Oil and Gas Industry. Asian Social Science, 9(7), 179-191.

Milaningrum, E., Rahmawati, P., Zulkifli, \& Mulyanto, S. (2019). Pelatihan Peningkatan Kemampuan Berkomunikasi Menggunakan Pelayanan Prima pada Industri Perhotelan di Balikpapan. Abdimas Universal, 1(2), 15-19.

Mohammadi, S., Kiumarsi, S., Hashemi, S. M., \& Niksima, B. (2016). An Investigation of Influential Factors on the Quality of Work Life and its Relationship with Employee Performance: A Case Study in Iran. IOSR Journal of Humanities and Social Science, 21(2), 73-78.

Murniasih, E., \& Sudarma, K. (2016). Pengaruh Persepsi Dukungan Organisasi dan Kompetensi pada Kinerja Karyawan dimediasi Komitmen Afektif. Management Analysis Journal, 5(1), 2435.

Murty, W. A. (2012). Pengaruh Kompensasi, Motivasi dan Komitmen Organisasional Terhadap Kinerja Karyawan Bagian Akuntansi (Studi Kasus Pada Perusahaan Manufaktur di Surabaya). 1-15.

Musta'in, M. M., Sanusi, A., \& Manan, A. (2014). A Study on Employees Performance: Spiritual Leadership and Work Motivation with Mediation Work Satisfaction at the University of Darul Ulum, Indonesia. European Journal of Business and Management, 6(39), 77-86.

Nayak, T., \& Sahoo, C. K. (2015). Quality of Work Life and Organizational Performance: The Mediating Role of Employee Commitment. Journal of Health Management, 17(3), 263-273.

Ojedokun, O., Idemudia, E. S., \& Desouza, M. (2015). Perceived External Prestige as a Mediator Between Quality of Work Life and Organisational Commitment of Public Sector Employees in Ghana. SA Journal of Industrial Psychology, 41(1), 1-10.

Pawirosumarto, S., Sarjana, P. K., \& Muchtar, M. (2017). Factors Affecting Employee Performance of PT. Kiyokuni Indonesia. International Journal of Law and Management, 59(4), 602-614.

Radja, J., Tawe, A., Rijal, S., \& Tiro, M. A. (2013). Effect Quality of Work Life And Organizational
Commitment Towards Work Satisfaction In Increasing Public Service Performance (A Study Of License Of Founding Building Service In Makassar City). Public Policy and Administration Research, 3(12), 38-46.

Rageb, M. A., Abd-el-salam, E. M., \& El-samadicy, A. (2013). Organizational Commitment, Job Satisfaction and Job Performance as a Mediator between Role Stressors and Turnover Intentions A Study from an Egyptian Cultural Perspective. International Journal of Business and Economic Development, 1(1), 34-54.

Rahmasari, M. R., \& Wulansari, N. A. (2020). Employee Performance Improvement Models. Management Analysis Journal, 9(1), 53-61.

Rahmawaty, A. (2016). Model Kepemimpinan Spiritual Dalam Meningkatkan Kepuasan Kerja Dan Kinerja Karyawan di BMT se-Kabupaten Pati. Iqtishad IA, 9(2), 276-303.

Ramadhoan. (2015). Kualitas Kehidupan Kerja Terhadap Kinerja Karyawan Melalui Komitmen Organisasional dan Kepuasan Kerja Sebagai Variabel Antara (Intervening Variable). Jurnal Ekonomi Pembangunan, 13(2), 198-217.

Ranihusna, D. (2010). Efek Rantai Motivasi pada Kinerja Karyawan. Jurnal Dinamika Manajemen, 1(2), 90-103.

Rawung, F. H. (2013). The Effect of Leadership on the Work Motivation of Higher Education Administration Employees (Study at Manado State University). IOSR Journal of Business and Management, 15(1), 28-33.

Raza, A., Saleem, S., \& Qamar, B. (2014). An Investigation of the Impact of Emotional Intelligence on Job Performance through the Mediating Effect of Organizational Commitment : An Empirical Study of Banking Sector of Pakistan. Information and Knowledge Management, 4(10), 19-27.

Rubel, M. R. B., \& Kee, D. M. H. (2014). Quality of Work Life and Employee Performance : Antecedent and Outcome of Job Satisfaction in Partial Least Square (PLS). Applied Sciences Journal 31, 31(4), 456-467.

Rumangkit, S. (2020). Mediator Analysis of Perceived Organizational Support: Role of Spiritual Leadership on Affective Commitment. Jurnal Dinamika Manajemen, 11(1), 47-54.

Salehzadeh, R., Pool, J. K., Lashaki, J. K., \& Dolati, H. (2015). Studying the Effect of Spiritual Leadership on Organizational Performance: An Empirical Study in Hotel Industry. International Journal of Culture Tourism and Hospitality Research, 9(3), 346-359.

Saraji, G. N., \& Dargahi, H. (2006). Study of Quality of Work Life (QWL). Iranian J Publ Health, 35(4), 8-14.

Srivastava, S., \& Pathak, D. (2016). Investigating the Mediating Effect of Psychological Empowerment on Quality of Work Life-Organisational Commitment Relationship: a Study on Indian IT Sector Managers. International Journal Man- 
agement Development, 1(3), 196-214.

Sugiyono. (2017). Metode Penelitian Kuantitatif, Kualitatif dan $R \& D$. Bandung: Alfabeta.

Suharsimi, A. (2010). Prosedur Penelitian suatu Pendekatan Praktik. Jakarta: PT Bina Aksara.

Swamy, D. R., Nanjundeswaraswamy, T., \& Rashmi, S. (2015). Quality of Work Life : Scale Development and Validation. International Journal of Caring Sciences, 8(2), 281-300.

Thakur, R., \& Sharma, D. (2019). A Study of Impact of Quality of Work Life on Work Performance. Management and Labour Studies, 44(3), 326-344.

Traiyotee, P., Taeporamaysamai, P., \& Saksamrit, N. (2019). Quality oef Work Life Affecting on Organizational Commitment through Organizational Citizenship Behavior: A Case Study of PT Gass Service Station Employees in the Northeast, Thailand. International Academic Research Conference in Vienna, (267-272), 267-272.

Twigg, N. W., \& Parayitam, S. (2007). Journal of Management, Spirituality \& Religion Spirituality as a Determinant of Transformational Leadership : Moderating Effects of Religious Orienta- tion. Journal of Management, Spirituality \& Religion, 4(3), 326-354.

Wartini, S., \& Harjiyanti, W. (2014). Organizational Commitment as the Black Box to Connect the Islamic Work Ethics and Employees Behavior Toward Organizational Change. Jurnal Dinamika Manajemen, 5(2), 228-240.

Wibowo, W., Eliyana, A., \& Irianto, D. (2015). The Effect of Spiritual Leadership, Organizational Culture, and Entrepreneurship on Employees' working Motivation And Performance In Property Companies At Yogyakarta Special Region. European Journal of Business and Management, 7(8), 206-219.

Widayanti, W., \& Palupiningdyah. (2019). The Effect of Quality or Work Life and Emotional Intelligence on Performance as Variable Organization Commitment Through Mediation. Management Analysis Journal, 8(1), 68-78.

Wulandari, K., \& Sudarma, K. (2017). Pengaruh Spiritualitas tempat Kerja, Kepemimpinna Spiritual, Kelebihan Beban Kerja pada Kepuasan Kerja. Management Analysis Journal, 6(2), 142-152. 